\title{
Korelasi TNF Alpha dan Interleukin 6 dengan Prognosis Stroke Infark Trombotik Akut
}

\section{Correlation of TNF Alpha and Interleukin 6 with Prognosis of Acute Thrombotic Infarction Stroke}

\author{
Gerry Gunawan ${ }^{1}$, Hidayat Sujuti', Hari Purnomo ${ }^{1}$ \\ ${ }^{1}$ Laboratorium IImu Penyakit Saraf Rumah Sakit Umum Daerah Dr. Saiful Anwar Malang \\ ${ }^{2}$ Laboratorium Biokimia Fakultas Kedokteran Universitas Brawijaya Malang
}

\begin{abstract}
ABSTRAK
Stroke adalah gangguan aliran darah ke otak yang terjadi mendadak dan bertahan dalam waktu lebih dari 24 jam yang dapat menimbulkan kecacatan. NIHHS merupakan alat ukur yang digunakan untuk menilai keluaran dari stroke. Penelitian ini bertujuan untuk mengetahui korelasi kadar TNF- $\alpha$ dan IL-6 serum dengan status neurologis pasien stroke infark trombotik akut yang dinilai dengan skor NIHSS awal, mengetahui korelasi antara tingginya kadar TNF- $\alpha$ dan IL-6 serum dengan perburukan status neurologis pasien stroke infark trombotik akut yang dinilai dengan delta skor NIHSS, mengetahui korelasi antara TNF- $\alpha$ serum dan IL-6 serum pasien stroke infark trombotik akut, dan mengetahui korelasi antara kadar TNF- $\alpha$ dan IL-6 serum dengan keluaran status neurologis pasien stroke infark trombotik akut yang dinilai dengan skor NIHSS akhir. Penelitian ini merupakan penelitian analitik observasional dengan melakukan pengambilan sampel darah dan pengukuran skor NIHSS pada jam ke 30 setelah onset stroke infark trombotik akut serta pengukuran skor NIHSS pada hari ke 10 setelah onset stroke infark trombotik akut. Sampel darah dilakukan pemeriksaan kadar TNF- $\alpha$ dan IL-6 serum dengan metode ELISA. Terdapat korelasi signifikan yang berbanding lurus antara skor NIHSS awal dengan kadar TNF- $\alpha$ dan IL-6 serum, skor NIHSS akhir dengan kadar TNF- $\alpha$ dan IL-6 serum, kadar IL-6 serum dengan kadar TNF- $\alpha$ serum. Terdapat korelasi signifikan yang berbanding terbalik antara delta skor NIHSS dengan kadar TNF- $\alpha$ dan IL-6 serum. Semakin tinggi kadar TNF- $\alpha$ dan IL-6 serum, maka prognosis akan semakin buruk.
\end{abstract}

Kata Kunci: IL-6, NIHSS, prognosis, TNF- $\alpha$, stroke trombotik

\begin{abstract}
Stroke is an interruption of blood flow to the brain that occurs suddenly, and persistence for more than 24 hours will cause disability. NIHHS is a measurement tool used to assess the output of a stroke. This study aims to determine the correlation levels of TNF- $\alpha$ and IL-6 serum with patients' neurological status in acute thrombotic infarction stroke assessed with initial NIHSS score, to know the correlation between high levels of TNF- $\alpha$ and IL-6 serum with worsening neurologic status of patients' acute thrombotic infarction stroke assessed using NIHSS delta scores, to determine the correlation between serum TNF- $\alpha$ and serum IL-6 of acute thrombotic infarction stroke patients, and to determine the correlation between the levels of TNF- $\alpha$ and IL-6 serum with output of neurological status of patients with acute thrombotic infarction stroke assessed using the final NIHSS score. This study is an analytic observational study by conducting blood sampling and measuring NIHSS scores at 30 hours after onset of acute thrombotic infarction and measuring NIHSS scores at day 10 after the onset of acute thrombotic infarction stroke. Blood samples were examined by checking the levels of TNF- $\alpha$ and IL-6 in serum using ELISA. There is a positive significant correlation among the initial NIHSS score with TNF- $\alpha$ and IL-6 serum, final NIHSS score with TNF- $\alpha$ and IL-6 serum, levels of IL-6 serum and levels of TNF- $\alpha$ serum. There was a negative correlation between NIHSS delta score with TNF- $\alpha$ and IL-6 serum. The higher levels of TNF- $\alpha$ and IL-6 serum, the worse the outcome.
\end{abstract}

Keywords: IL-6, NIHSS, Prognosis, Thrombotic Stroke, TNF- $\alpha$

Jurnal Kedokteran Brawijaya, Vol. 28, No. 4, Agustus 2015; Korespondensi: Gerry Gunawan. Laboratorium Ilmu Penyakit Saraf Rumah Sakit Umum Daerah Dr. Saiful Anwar Malang, Jl. Jaksa Agung Suprapto No. 2 Malang Tel. (0341) 366242 Email: gerrygunawanagain@yahoo.com 


\section{PENDAHULUAN}

Stroke adalah penyakit yang kedua yang paling banyak menyebabkan kematian di dunia dan penyebab kematian ketiga di Amerika serikat setelah penyakit jantung dan kanker (1). Di Amerika Serikat, stroke infark trombotik merupakan kasus stroke yang paling banyak terjadi dari seluruh jenis stroke dengan prevalensi 82 sampai 92\% (2).

Pada $25 \%$ sampai $40 \%$ pasien dengan stroke infark, gejala penurunan neurologis berkembang selama jam-jam awal sejak onset. Penurunan status neurologis awal menyebabkan peningkatan mortalitas dan disabilitas fungsional pada pasien stroke infark trombotik. Mekanisme dasar yang menyebabkan penurunan status neurologis awal pada pasien dengan stroke infark trombotik masih belum dimengerti dengan jelas (3).

Selama beberapa tahun terakhir, terdapat bukti bahwa inflamasi berperan dalam patofisiologi iskemia otak akut. Hampir semua reaksi inflamasi diperantarai oleh sitokin, glikoprotein kecil yang diekspresikan oleh berbagai tipe sel sebagai respon terhadap iskemia serebral akut. Pelepasan sitokin menyebabkan upregulasi molekul adhesi, rekrutmen dan aktivasi leukosit, peningkatan interaksi leukosit-endotel, dan konversi endotel lokal menjadi kondisi protrombotik (4). Mediator respon inflamasi kunci adalah sitokin proinflamasi tumor necrosis factor- $\alpha$ (TNF- $\alpha)$, walaupun sitokin lain seperti interleukin-6 (IL-6) juga meningkat selama inflamasi (5-7).

Sitokin proinflamasi TNF- $\alpha$ dan IL-6 merupakan mediator inflamasi kunci yang berperan pada neuroinflamasi dan mempunyai keterkaitan dengan perburukan gejala pada pasien stroke infark trombotik akut. Penilaian keluaran stroke infark trombotik dapat dinilai dengan skala NIHHS (National Institutes of Health Stroke Scale). NIHSS di Amerika Serikat digunakan secara luas untuk penilaian awal dan defisit neurologis akhir pada semua penelitian stroke $(2,8)$.

Penelitian ini bertujuan untuk mengetahui korelasi kadar TNF- $\alpha$ dan IL- 6 serum dengan status neurologis pasien stroke infark trombotik akut yang dinilai dengan skor NIHSS awal, mengetahui korelasi antara tingginya kadar TNF- $\alpha$ dan IL-6 serum dengan perburukan status neurologis pasien stroke infark trombotik akut yang dinilai dengan delta skor NIHSS, mengetahui korelasi antara TNF$\alpha$ serum dan IL-6 serum pasien stroke infark trombotik akut, dan mengetahui korelasi antara kadar TNF- $\alpha$ dan IL6 serum dengan keluaran status neurologis pasien stroke infark trombotik akut yang dinilai dengan skor NIHSS akhir.

\section{METODE}

Penelitian ini merupakan studi analitik observasional yang meneliti korelasi antara kadar TNF- $\alpha$ (tumor necrosis factor- $\alpha$ ) dan IL-6 (interleukin-6) serum pasien stroke infark trombotik akut dengan status neurologis (dinilai dengan skor NIHSS) pada jam ke 30 setelah onset stroke, korelasi antara tingginya kadar TNF- $\alpha$ dan IL- 6 serum awal dengan perburukan pasien stroke infark trombotik akut dengan status neurologis (dinilai dengan selisih skor NIHSS awal dikurangi skor NIHSS hari ke 10), meneliti korelasi antara kadar TNF- $\alpha$ dan IL-6 serum awal pasien stroke infark trombotik akut, serta meneliti korelasi antara kadar TNF- $\alpha$ dan IL-6 serum awal dengan keluaran status neurologis pasien stroke infark trombotik akut yang dinilai dengan skor NIHSS akhir. Pada penelitian ini tidak didapatkan kelompok kontrol, dengan subjek adalah 37 pasien stroke infark trombotik akut yang telah didiagnosis berdasarkan klinis dan CT Scan Kepala dan MRS di RS dr Saiful Anwar Malang dimasukkan sebagai subjek penelitian.

Data penelitian terdiri dari sampel darah pasien yang diambil pada jam ke 30 setelah onset stroke infark trombotik untuk diperiksa kadar TNF- $\alpha$ dan IL-6 serum dengan metode ELISA. Skor NIHSS dihitung bersamaan dengan pengambilan darah dan pada hari ke 10 setelah onset stoke infark trombotik. Analisis data menggunakan bantuan software SPSS versi 17.0. Uji normalitas data dengan menggunakan uji Kolmogorov Smirnov, dan uji korelasi Pearson. Hasil uji bermakna jika nilai $p<0,05$.

\section{HASIL}

\section{KarakteristikSubjek}

Penelitian ini melibatkan 37 pasien sebagai subjek penelitian yang telah memenuhi kriteria inklusi yang nantinya akan diukur skor NIHSS awal dan akhir serta kadar IL-6 serum dan TNF- $\alpha$ serum. Dari 37 subjek penelitian terdapat 16(43,2\%) laki-laki dan $21(56,8 \%)$ perempuan, dengan rata-rata usia 53,70 $\pm 5,206$ tahun (Tabel 1).

Tabel 1. Karakteristik subjek

\begin{tabular}{lr}
\hline Karakteristik Subjek & Stroke Infark Trombotik $(\mathbf{n}=\mathbf{3 7})$ \\
\hline Jenis kelamin: & \\
Laki-laki & $16 / 37(43)$ \\
Perempuan & $21 / 37(56)$ \\
Mean Usia \pm SD (tahun) & $53,70 \pm 5,206$ \\
Mean Sistolik \pm SD $(\mathrm{mmHg})$ & $160,81 \pm 18,764$ \\
Mean Diastolik \pm SD $(\mathrm{mmHg})$ & $94,32 \pm 8,347$ \\
Mean NIHSS Awal \pm SD & $7,4 \pm 2,165$ \\
Mean NIHSS Akhir \pm SD & $4,43 \pm 2,986$ \\
Mean TNF $\alpha \pm$ SD $(\mathrm{pg} / \mathrm{ml})$ & $3,761 \pm 0,609$ \\
Mean IL- \pm \pm SD $(\mathrm{pg} / \mathrm{ml})$ & $4.490 \pm 0,614$ \\
\hline
\end{tabular}

Hubungan antara Skor NIHSS Awal, dengan Skor NIHSS akhir, Kadar TNF- $\alpha$, dan IL-6 serum

Uji korelasi Pearson untuk skor NIHSS awal terhadap kadar TNF- $\alpha$ menunjukkan nilai signifikansi $(P$-value $)=0,000$ dan Pearson correlation coefficient $(r)=0,981$ yang berarti terdapat korelasi signifikan antara dua variable. Pearson correlation coefficient $(r)$ bernilai positif $(+)$ berarti korelasinya berbanding lurus, yang artinya semakin tinggi kadar TNF- $\alpha$, maka semakin besar skor NIHSS awal, dan sebaliknya semakin rendah kadar TNF- $\alpha$ maka semakin kecil skor NIHSS awal. Korelasi antara skor NIHSS awal dan kadar TNF- $\alpha$ sangat kuat $(r>0,799)$.

Tabel 2. Hasil uji korelasi pearson

\begin{tabular}{ccc}
\hline Korelasi antara & Koefisien Korelasi $(\mathbf{r})$ & p-value \\
\hline NIHSS awal: & & \\
TNF- $\alpha$ serum & 0,981 & 0,000 \\
IL-6 serum & 0,980 & 0,000 \\
Delta NIHSS: & & \\
TNF- $\alpha$ serum & $-0,910$ & 0,000 \\
IL-6 serum & $-0,890$ & 0,000 \\
\hline
\end{tabular}


Tabel 2. Hasil uji korelasi pearson (Lanjutan)

\begin{tabular}{ccc}
\hline \multicolumn{1}{c}{ Korelasi antara } & Koefisien Korelasi $(\mathbf{r})$ & p-value \\
\hline TNF- $\alpha$ serum IL-6 serum & 0,982 & 0,000 \\
NIHSS akhir: & & \\
TNF- $\alpha$ serum & 0,978 & 0,000 \\
IL-6 serum & 0,972 & 0,000 \\
\hline
\end{tabular}

Keterangan: Jika $p$-value $<0,05$ menunjukkan adanya korelasi yang signifikan

Uji korelasi Pearson untuk skor NIHSS awal terhadap kadar IL-6 menunjukkan nilai signifikansi $(P$-value $)=0,000$ $(p<0,05)$ dan Pearson correlation coefficient $(r)=0,980$ yang berarti.Semakin tinggi kadar IL-6, maka semakin besar skor NIHSS awalnya dan sebaliknya. Hasil juga menunjukkan terdapat hubungan negative yang signifikan antara selisih skor NIHSS awal dan akhir (delta NIHSS) terhadap kadar TNF- $\alpha$ menunjukkan nilai signifikansi $(P$ value $=0,000, r=-0,910)$. Semakin tinggi kadar TNF- $\alpha$, maka semakin kecil delta NIHSS dan sebaliknya.

Hubungan selisih skor NIHSS awal dan akhir (delta NIHSS) terhadap kadar IL-6 menunjukkan korelasi berbanding terbalik dan sangat kuat $(P$-value $=0,000, r=-0,890)$ yang berarti semakin tinggi kadar IL-6, maka semakin kecil delta NIHSS dan sebaliknya. Uji korelasi Pearson untuk kadar IL-6 terhadap kadar TNF- $\alpha$ juga menunjukkan korelasi berbanding lurus dan sangat kuat $(P$ value) $=0,000 ; r=0,982$ ). Artinya semakin tinggi kadar TNF$\alpha$, maka semakin tinggi pula kadar IL-6, dan sebaliknya.

Skor NIHSS akhir terhadap kadar TNF- $\alpha$ juga menunjukkan korelasi berbanding lurus dan sangat kuat ( $P$-value $=0,000, r=0,978)$ yang berarti terdapat semakin tinggi kadar TNF- $\alpha$, maka semakin tinggi pula skor NIHSS akhir, dan sebaliknya. Uji korelasi Pearson untuk skor NIHSS akhir terhadap kadar IL-6 menunjukkan korelasi berbanding lurus dan sangat kuat $(P$-value $=0,000$; $r=0,972$ ) yang berarti semakin tinggi kadar IL-6, maka semakin tinggi pula skor NIHSS akhir. Secara keseluruhan dapat disimpulkan bahwa prognosis stroke yang diukur dengan skor NIHSS mempunyai korelasi kuat dengan kadar TNF- $\alpha$ dan IL-6.

\section{DISKUSI}

Pada penelitian ini, sebanyak 45 pasien dilibatkan dalam penelitian karena memenuhi kriteria inklusi dari penelitian ini. Dalam perjalanannya 8 pasien dieksklusi dari penelitian. Dari 37 pasien yang tersisa, 16 (43,2\%) berjenis kelamin laki-laki dan 21 (56,8\%) perempuan, dengan rata-rata usia 53,70 $\pm 5,206$ tahun. Data ini berbeda dengan insiden stroke infark trombotik berdasarkan penelitian sebelumnya yang lebih banyak menyerang laki-laki dibandingkan dengan perempuan. Karakteristik subjek yang lebih banyak perempuan dibanding laki-laki dapat disebabkan karena batasan usia pada penelitian ini antara 30-60 tahun dengan rata-rata usia 53,70 $\pm 5,206$ tahun. Pada usia lebih dari 50 tahun, perempuan akan mengalami fase menopause yang mana hal ini akan menyebabkan perempuan lebih rentan menderita stroke infark trombotik jika dibandingkan dengan laki-laki dengan usia yang sama.

Tumor necrosis factor- $\alpha$ (TNF- $\alpha$ ) dan interleukin-6 (IL-6) merupakan sitokon proinflamasi, yang merupakan mediator inflamasi kunci yang berperan pada neuroinflamasi dan mempunyai keterkaitan dengan perburukan gejala pada pasien stroke infark trombotik akut $(2,5,7)$. Pada penelitian ini skor NIHSS awal dibandingkan dengan kadar TNF- $\alpha$ serum dan IL-6. Hasil menunjukkan semakin tinggi skor NIHSS awal maka semakin tinggi pula kadar TNF- $\alpha$ serum ataupun kadar IL- 6 serum dan sebaliknya, semakin rendah kadar TNF- $\alpha$ serum atau kadar IL-6 serum maka skor NIHSS awal akan rendah pula. Berdasarkan studi sebelumnya TNF- $\alpha$ di-upregulasi pada otak setelah terjadinya infark. Kenaikan awal akan terlihat pada 1-3 jam setelah onset infark dan kadarnya mencapai puncak pada 24-36 jam setelah onset infark (9). Penelitian ini sesuai dengan studi tersebut, yang mengidentifikasi peningkatan kadar TNF- $\alpha$ serum. Pada penelitian ini delta skor NIHSS juga dibandingkan dengan kadar TNF- $\alpha$ serum. Dari hasil uji statistik menunjukkan semakin tinggi kadar TNF- $\alpha$ serum, maka semakin kecil delta skor NIHSS, dan sebaliknya. Pada penelitian ini juga membandingkan antara kadar TNF- $\alpha$ serum dengan skor NIHSS akhir. Kadar TNF- $\alpha$ serum memiliki korelasi yang signifikan dan berbanding lurus jika dibandingkan dengan skor NIHSS akhir. Hal ini menunjukkan semakin tinggi kadar TNF- $\alpha$ serum maka keluaran dari penderita stroke infark trombotik akan semakin buruk, dan semakin rendah kadar TNF- $\alpha$ serum maka keluaran dari pasien stroke infark trombotik akan semakin baik.

Penelitian Tso et al menunjukkan bahwa pada pasien dengan stroke infark trombotik memilliki kadar IL-6 serum meningkat secara signifikan (10). Dari penelitian ini juga didapatkan peningkatan kadar IL-6 serum pada pasien stroke infark trombotik. Pada penelitian ini delta dari Skor NIHSS juga dibandingkan dengan kadar IL-6 serum. Dari hasil uji statistik diperoleh bahwa delta skor NIHSS memiliki korelasi yang signifikan terhadap kadar IL-6 serum, dengan korelasi yang berbanding terbalik. Penelitian ini juga membandingkan antara kadar IL-6 serum dengan skor NIHSS akhir. Kadar IL-6 serum memiliki korelasi yang signifikan dan berbanding lurus jika dibandingkan dengan skor NIHSS akhir. Hal ini menunjukkan semakin tinggi kadar IL-6 serum maka keluaran dari penderita stroke infark trombotik akan semakin buruk, dan semakin rendah kadar IL-6 serum maka keluaran dari pasien stroke infark trombotik akan semakin baik.

Semakin besar delta skor NIHSS maka perbaikan klinis dari pasien semakin besar, dan sebaliknya jika semakin kecil delta NIHSS maka perbaikan klinis dari pasien akan sedikit jika dibandingkan awal. Dari hasil penelitian ini didapatkan delta skor NIHSS memiliki korelasi secara signifikan terhadap kadar TNF- $\alpha$ serum maupun terhadap kadar IL-6 serum. Dapat disimpulkan bahwa kadar TNF- $\alpha$ serum maupun kadar IL-6 serum dapat dijadikan sebagai salah satu faktor penentu dari prognosis stroke infark trombotik. Semakin tinggi kadar TNF- $\alpha$ serum dan IL-6 serum maka prognosis akan semakin buruk, sedangkan semakin rendah kadar TNF- $\alpha$ serum dan IL- 6 serum maka prognosis akan semakin baik. TNF- $\alpha$ dan IL- 6 merupakan sitokin proinflamasi yang berperan pada neuroinflamasi dan mempunyai keterkaitan dengan perburukan gejala pada pasien stroke infark trombotik akut. Adanya peningkatan kadar TNF- $\alpha$ dan IL- 6 menyebabkan prognosis dari penderita stroke infark trombotik menjadi semakin buruk.Selain itu, prognosis stroke infark trombotik juga dipengaruhi oleh beberapa faktor eksternal seperti 
kepatuhan pasien dalam mengkonsumsi obat, serta kemauan pasien untuk menjalani program rehabilitasi pasca stroke (2).

Kadar TNF- $\alpha$ serum awal juga memiliki korelasi yang signifikan terhadap kadar IL-6 serum. Keduanya

\section{DAFTAR PUSTAKA}

1. Hinkle JL and Guanci M. Acute Ischemic Stroke Review. Journal Neuroscience Nursing. 2007; 39(5): 285-293.

2. Jauch EC. Ischemic Stroke. (Online) September 2014. http://www.emedicine.medscape.com [diakses tanggal 1 Maret 2014].

3. Maas MB and Furie KL. Molecular Biomarkers in Stroke Diagnosis and Prognosis. Biomarkers in Medicine. 2009; 3(4): 363-383.

4. Dirnagl U, Ladecola C, and Moskowitz MA. Pathobiology of Ischaemic Stroke: An Integrated View. Trends in Neurosciences. 1999; 22(9): 391-7.

5. Dong $\mathrm{Y}$ and Benveniste EN. Immune Function of Astrocytes. GLIA. 2001; 36(2): 180-190.

6. Ladecola C and Anrather J. The Immunology of Stroke: berbanding lurus, artinya semakin tinggi kadar TNF- $\alpha$ serum maka kadar IL-6 serum akan tinggi. Penelitian ini membuktikan bahwa untuk menentukan prognosis dari stroke infark trombotik akut dapat dilakukan dengan pengukuran kadar TNF- $\alpha$ serum atau kadar IL- 6 serum, maupun pengukuran dari kedua serum tersebut.

From Mechanisms to Translation. Nature Medicine. 2011; 17(7): 796-808.

7. Amantea D, Nappi G, Bernardi G, Bagetta G, and Corasaniti MT. Post-Ischemic Brain Damage: Pathophysiology and Role of Inflammatory Mediators. The FEBS Journal. 2009 Jan; 276(1): 13-26.

8. Jensen MB and Lyden P. Stroke Scale: An Updates. Stroke Clinical Updates. 2006; 16: 1-7.

9. Wang $\mathrm{Q}$, Tang $\mathrm{XN}$, and Yenari MA. The Inflammatory Response in Stroke. Journal Neuroimmunology. 2007; 184(1-2): 53-68.

10. Tso AR, Merino JG, and Warach S. Interleukin-6174G/C Polymorphism and Ischemic Stroke a Systematic Review. The American Journal of Stroke. 2007; 38: 3070-3075. 